\title{
Review
}

\section{Pi Alpha Xi-A Tradition of Excellence in Floriculture, Landscape Horticulture, and Ornamental Horticulture}

\author{
Mary Lewnes Albrecht
}

Additional INDEX wOrds. history of horticulture, honor society

Summary. Pi Alpha Xi, founded in 1923 , is the national honor society for floriculture, landscape horticulture and ornamental horticulture. Since its founding, it has grown to 36 chapters at baccalaureate-granting institutions. Its mission is to promote scholarship, fellowship, professional leadership, and the enrichment of human life through plants.
Professor and associate dean for academic programs, University of Tennessee, 125 Morgan Hall, Knoxville, TN 37996-4500; e-mail mlalbrecht@utk.edu.

The author was inducted into the Zeta Chapter, Rut gers University (New Brunswick, N.J.), and has been a member or advisor of three other Phi Alpha Xi chapters: Epsilon, The Ohio State University (Columbus); Omega, Kansas State University (Manhattan); and Alpha Beta, The University of Tennessee (Knoxville). The author gratefully acknowledges the assistance provided by Dr. Doug Needham of Oklahoma State University (Stillwater) and Pi Alpha Xi web master and Dr. Dave Graper of South Dakota State University (Brookings) and 2000-02 Pi Alpha Xi National President, in the preparation of this manuscript.
W hat do 25 American Society for Horticultural Science presidents (Table 1) from Liberty Hyde Bailey, the first ASHS president, to Dan Lineberger, our current president, all have in common? They are all members of Pi Alpha Xi.

Pi Alpha Xi (PAX) was founded in 1923. The idea to form an honor society for those in floriculture, as told in the Ritual for the Initiation Ceremony, came from "an impromptu, after-dinner discussion among representatives of several universities attending the International Flower Show held [in] New York City in 1923. A group of individuals from Cornell University (Ithaca, N.Y.), led by the late Arno Nehrling, developed the organization, wrote the first constitution and ritual and designed the insignia. The formal installation of the Alpha Chapter was at Cornell University on June 1, 1923 , after nearly 2 years of effort on Professor Nehrling's part to organize an honor society (PAX, 1988d).

Over the first five decades, PAX saw very little growth. The only chapters organized during that time were Alpha (Cornell University), Beta (University of Illinois, Urbana), Gamma (The Pennsylvania State University, University Park), Delta (Michigan State University, East Landsing), Epsilon (The Ohio State University, Columbus), and Zeta (Rutgers University, New Brunswick, N.J.). During the 1970s, PAX saw its greatest expansion with 18 chapters being established in the decade (PAX, 1975b, 1978 , 1980b). As horticulture programs grew in breadth and student numbers, PAX expanded membership from solely floriculture students, faculty and industry members to include those in landscape horticulture and ornamental horticul- ture. Only the top students in the junior and senior classes with a demonstrated interest in floriculture, landscape horticulture, and/or ornamental horticulture are invited to join. Graduate students and faculty members with an emphasis in these fields are also eligible. Candidates should show promise of continued activity and interest in the field.

The honor society, originally established to unify students, educators, and professional horticulturists, was formed to promote high scholarship, fellowship, professional leadership, and the enrichment of human life through plants. In fact, the name Pi Alpha Xi comes from three Greek words, each starting with one of the letters in the honor society's name. $\mathrm{Pi}$ is the first letter of the Greek word, Polumathia, meaning scholarship. Alpha, the second word in the society's name, is from the Greek word, Anthemorgous, meaning to work with plants. Xi represents the Greek word, Zunoia, meaning mutual kindness signifying companionship, the bond among gardeners, educators and professional horticulturists (PAX, 2000b).

Today there are 36 chapters (Table 2 ) and nearly 12,000 members. These chapters are located in the United States at 4-year institutions with programs in floriculture, landscape horticulture, and ornamental horticulture. The level of chapter activity varies. Some chapters exist solely to recognize academic excellence through the initiation of new members. Others offer an array of activities to their members, such as sponsored lectures by visiting professors and other professionals, sponsored field trips to horticultural sites, and support for student travel to the ASHS annual conference and the National Intercollegiate Floral Crop Quality Evaluation and Design Competition. Operating budgets for chapters come from a variety of sources including departmental funding, dues to the local chapters, student activities funds, fundraisers such as plant sales, conducting fee-based horticultural workshops, and support from local members of the horticulture industry. If you are located at an institution with an inactive chapter and are interested in reactivating it, contact the national president of PAX. Current officers are listed at the PAX National (the name used to distinguish national organization from its chapters) web site at 
Table 1. ASHS presidents who have been initiated into Pi Alpha Xi.

\begin{tabular}{lll}
\hline President $^{\mathbf{z}}$ & Term in office (year) & Chapter (member no.) \\
\hline Liberty Hyde Bailey & $1903-1907$ & Alpha $(27)$ \\
Maurice A. Blake & 1916 & Zeta $(8)$ \\
Joseph C. Blair & 1922 & Beta $(19)$ \\
Joseph Harvey Gourley & 1923 & Epsilon $(50)$ \\
Ezra J. Kraus & 1927 & Zeta \\
Alex Laurie & 1936 & Delta $(1)$ \\
Laurence H. MacDaniels & 1940 & Alpha $(168)$ \\
Warren B. Mack & 1945 & Gamma $(77)$ \\
Harold B. Tukey, Sr. & 1947 & Delta $(132)$ \\
Samuel L. Emsweller & 1950 & Theta \\
Kenneth Post & 1952 & Delta $(2)$ \\
Milton B. Davis & 1956 & Gamma $(107)$ \\
Freeman S. Howlett & 1959 & Epsilon $(108)$ \\
Howard A. Rollins, Sr. & 1960 & Kappa $(9)$ \\
Vernon T. Stoutemyer & 1961 & Beta $(32)$ \\
Russell E. Larson & 1964 & Gamma $(174)$ \\
H. John Carew & 1966 & Gamma (65) \\
Neil W. Stuart & 1968 & Theta $(42)$ \\
John P. Mahlstede & 1972 & Delta $(122)$ \\
Charles E. Hess & 1973 & Zeta $(67)$ \\
John G. Seeley & 1983 & Zeta $(21)$ \\
Roy A. Larson & 1989 & Alpha $(339)$ \\
Thomas A. Fretz & 1992 & Theta $(92)$ \\
John W. Kelly & 2000 & Pi $(23)$ \\
R. Daniel Lineberger & 2002 & Alpha $(481)$ \\
& &
\end{tabular}

${ }^{2}$ Presidents and years in office as listed in the ASHS Membership Directory, 2001

yPi Alpha Xi membership information from The Lotus Leaf (Pi Alpha Xi, 1975a, 1980).

<http://www.pax.okstate.edu> (PAX, 2002 d).

While all current chapters are hosted by institutions in the United States, the constitution and bylaws do not prohibit formation of chapters outside the United States. According to the constitution and bylaws of the PAX National, "any university or college offering 4 years of baccalaureate instruction in floriculture, landscape horticulture or ornamental horticulture is eligible to establish a chapter" (PAX, 2000c). More detailed information is available at the PAX National web site (PAX, 2002d). Once the required documentation is reviewed by the PAX National Board of Directors, the petition is submitted to current chapters for review and a vote. Approval is granted if there is an affirmative vote by $2 / 3$ of the active PAX chapters (PAX, 2000d).

The goals of PAX National are promoted through the work of the individual chapters and by PAX National. Before the 1990s, the main activities of PAX National were the National Intercollegiate Floral Crop Quality Evaluation and Design Competition (cosponsored by the American Floral Endowment) and the pub- lication of the Pi Alpha Xi Flower Judging Manual(PAX, 1998, 2002a). The PAX Fellows Program was added in 1986 by the Board of Directors (PAX, 1988b, 1988c). Beginning in 1991 when ASHS held its annual conference at University Park, Pa., PAX National began to hold its business meeting in conjunction with the ASHS conference. Before that business meeting, the annual business meeting was held in the spring in conjunction with the Intercollegiate Flower Judging Contest and was attended primarily by the flower judging team coaches. By making the switch in meeting time, a broader segment of the membership could participate. PAX National instituted the Pi Alpha Xi Annual Photography Contest, held each year since 1996 in conjunction with the annual ASHS conference, and started a scholarship program (PAX, 1996).

\section{National intercollegiate floral crop quality evaluation and design competition}

The first intercollegiate flower judging contest was held in 1938 in Toronto, Canada. In the early years, the contest was held in major cities away from college campuses with generally fewer than ten teams competing. Then in 1955, The Ohio State University became the first school to host an on-campus contest. With the exception of 1979 when the contest was cohosted by the University of Georgia (Athens) and Auburn University (Auburn, Ala.) at Callaway Gardens in Pine Mountain, Ga., the contest has remained on college campuses (PAX, 1988a). During the 1970s when horticulture programs saw tremendous growth in undergraduate enrollment, the flower judging contest also saw an increase in participation peaking at 24 teams participating in the 1979 contest at Callaway Gardens. In 1993, the name of the contest was updated to its present name (PAX, 1993). The $60^{\text {th }}$ annual competition, held in 2001 , was hosted by California Polytechnic State University-San Luis Obispo. The 2002 contest was hosted by the University of Wisconsin-River Falls; in 2003, it will be hosted by New Mexico State University, Las Cruces.

Recently, the annual competition generally attracts teams from about 10 to 15 universities. Teams can enter the crop quality evaluation competition [about 25 to 30 classes of plant material each with four specimens (individual potted plants or containers of cut flowers of varying quality)], the design competition (amateur and professional divisions), or both (PAX, $2002 \mathrm{~b}, 2002 \mathrm{c}$ ). Training for the competition varies by school. Most either offer the training as a for-credit course or as an extracurricular activity. Training develops an understanding by students about high quality plant material and trains them to identify quality characteristics. The vehicle used is traditional floriculture crops - potted flowering and foliage plants, fresh cut flowers, and plants in hanging baskets - however, the basic principles of plant quality can be applied to nursery stock, fruits, and vegetables, as well.

The host institution will arrange industry tours for the competing teams. The floral design portion of the competition is judged by local, leading floral designers. Students often have the opportunity to have their design work critiqued by American Institute of Floral Design (AIFD) certified designers. To help prepare new coaches and students, PAX National publishes the Pi Alpha Xi Flower Judging 
Table 2. Chapters of Pi Alpha Xi as of August 2001.

\begin{tabular}{|c|c|}
\hline Chapter & Institution \\
\hline Alpha & Cornell University, Ithaca, N.Y. \\
\hline Beta & University of Illinois, Urbana \\
\hline Gamma & Pennsylvania State University, University Park \\
\hline Delta & Michigan State University, East Lansing \\
\hline Epsilon & The Ohio State University, Columbus \\
\hline Zeta & Rutgers University, New Brunswick, N.J. \\
\hline Eta & Washington State University, Pullman \\
\hline Theta & University of Maryland, College Park \\
\hline Iota & North Carolina State University, Raleigh \\
\hline Kappa & Virginia Polytechnic \& State University, Blacksburg \\
\hline Lambda & University of Minnesota, St. Paul \\
\hline $\mathrm{Mu}$ & University of Florida, Gainesville \\
\hline $\mathrm{Nu}$ & Auburn University, Auburn, Ala. \\
\hline $\mathrm{Xi}$ & New Mexico State University, Las Cruces \\
\hline Omicron & Purdue University, West Lafayette, Ind. \\
\hline $\mathrm{Pi}$ & Clemson University, Clemson, S.C. \\
\hline Rho & University of Wisconsin-Madison \\
\hline Sigma & Southern Illinois University, Carbondale, Ill. \\
\hline Tau & University of Georgia, Athens \\
\hline Upsilon & California Polytechnic State University-San Luis Obispo \\
\hline Phi & South Dakota State University, Brookings \\
\hline Chi & Colorado State University, Fort Collins \\
\hline Psi & Texas A\&M University, College Station \\
\hline Omega & Kansas State University, Manhattan \\
\hline Alpha Beta & University of Tennessee, Knoxville \\
\hline Alpha Gamma & University of Nebraska-Lincoln \\
\hline Alpha Delta & Oklahoma State University, Stillwater \\
\hline Alpha Epsilon & University of California-Davis \\
\hline Alpha Zeta & University of Wisconsin-River Falls \\
\hline Alpha Eta & Delaware Valley College of Science \& Agriculture, Doylestown, Pa. \\
\hline Alpha Theta & Iowa State University, Ames \\
\hline Alpha Iota & Texas Tech University, Lubbock \\
\hline Alpha Kappa & Mississippi State University, Mississippi State \\
\hline Alpha Lambda & Florida A\&M University, Tallahassee \\
\hline Alpha $\mathrm{Mu}$ & Temple University, Philadelphia, Pa. \\
\hline Alpha $\mathrm{Nu}$ & Utah State University, Logan \\
\hline
\end{tabular}

Table 3. Fellows of Pi Alpha Xi.

\begin{tabular}{lll}
\hline Member & Chapter (member no.) & Year awarded \\
\hline Lewis Charles "Chad" Chadwick & Alpha (51) & 1989 (deceased) \\
G.H. "Gus" Poesch & Delta (10) & 1989 (deceased) \\
Roy A. Larson & Alpha (339) & 1992 \\
James B. Shanks & Epsilon (70) & 1992 \\
Harold Wilkins & Beta $(162)$ & 1992 \\
Elwood "Woody" Kalin & Delta (48) & 1993 (deceased) \\
Lou Berninger & Delta (15) & 1994 \\
Marlin N. Rogers & Alpha (319) & 1994 \\
James E. Klett & Epsilon (394) & 1995 \\
Kenneth C. Sanderson & Alpha (305) \\
Dennis J. Wolnick & Gamma (323) & 1995 \\
John R. Culbert & Beta (72) & 1995 \\
Marvin C. Carbonneau & Beta (155) & 1998 \\
Robert W. Langhans & Zeta (68) & 1998 \\
Terri L. Ferriss & Chi $(12)$ & 2000 \\
& & 2000
\end{tabular}

Manual, now in its eighth edition (PAX, 1998, 2002a).

\section{Photography contest}

The annual photography contest is open to PAX and ASHS members and held in conjunction with the ASHS annual conference. The annual contest, conceived by Dr. Richard Criley, the University of Hawaii (Honolulu), contributes to the goals of PAX by bringing students, faculty members and industry professionals together (PAX, 1996). Entries are displayed in the same hall as the research posters. Proceeds from the contest help support the PAX Scholarship Program (see the Scholarship Program section). Participants may enter $20.3 \times 25.4 \mathrm{~cm}$ $(8 \times 10$ inches $)$ or $21.6 \times 30.5 \mathrm{~cm}(8.5$ $\times 12$ inches) photographs in three categories: flower (a flower, flowers, flower parts, or a flower arrangement), ornamental [an ornamental plant(s), foliage, branches, berries, buds or combinations], and landscape (a landscape or interiorscape scene with plants as the principal focus; with or without people). The contest is announced in the ASHS newsletter each year, generally one to three months in advance of the annual ASHS conference. Contest rules are posted on the PAX web site (PAX, 2000e). Judges are selected by the PAX National vice president in consultation with faculty members of the host institution. Either ASHS members or local professional photographers are asked to serve.

\section{PAX fellows}

The inaugural class of Fellows was inducted at the 1989 annual business meeting of PAX National. The Fellows Award (Table 3 ) "is given to [PAX] members who have achieved marked service or excellence in the field of Floriculture, Landscape Horticulture, or Ornamental Horticulture and/or distinguished themselves with meritorious service to [PAX]" (PAX, 2000a). No more than twenty-five of the living membership of PAX shall be elected as Fellows. Nominations are due three months before the annual PAX business meeting held in conjunction with the ASHS annual conference.

\section{Scholarship program}

At the 1995 annual business meeting held in Montréal, Que., Canada, PAX members approved the establishment of a program to provide match- 
ing funds for local chapters' scholarships. The goal of the PAX National Scholarship Program, by providing some matching dollars, is to encourage chapters to provide scholarships to deserving students. PAX National provides matching funds annually up to $\$ 100$ to each active chapter for support of a scholarship. Full procedures are available from the PAX web site (PAX, 2002f).

\section{Literature cited}

Pi Alpha Xi. 1975a. Members of Pi Alpha Xi. The Lotus Leaf. p. 26-51.

Pi Alpha Xi. 1975b. President's address. The Lotus Leaf. p. 4.

Pi Alpha Xi. 1978. Chapters. The Lotus Leaf. p. 1.

Pi Alpha Xi. 1980a. Pi Alpha Xi members through September 1, 1980. The Lotus Leaf. p. 77-114.

Pi Alpha Xi. 1980b. Pi Alpha Xi National, report of the secretary, March 29, 1979. The Lotus Leaf. p. 6-7.

Pi Alpha Xi. 1988a. Intercollegiate flower judging contests. The Lotus Leaf. p. 4042.
Pi Alpha Xi. 1988b. Minutes of the Pi Alpha Xi national annual business meeting, April 4, 1986. The Lotus Leaf. p. 18.

Pi Alpha Xi. 1988c. Minutes of the Pi Alpha Xi national annual business meeting, April 2, 1987. The Lotus Leaf. p. 26.

Pi Alpha Xi. 1988d. Ritual for the initiation ceremony. The Lotus Leaf. p. 84.

Pi Alpha Xi. 1993. 52 $2^{\text {nd }}$ National intercollegiate floral crop quality evaluation contest. The Lotus Leaflet. spring issue, p. 1.

Pi Alpha Xi. 1996. Letter from the president. The Lotus Leaflet. Winter issue, p. 1.

Pi Alpha Xi. 1998. A manual for flower judging. 8th ed. Dept. Plant and Earth Science, Univ. Wis., River Falls.

Pi Alpha Xi. 2000a. By-laws of national constitution of Pi Alpha, section XI, fellows award, revised 1992-1994. 16 Apr. 2002. < http://www.pax.okstate.edu/ PDFs/c_bylaws.pdf $>$.

Pi Alpha Xi. 2000b. Initiation of members. 16 Apr. 2002. <http://www.pax. okstate.edu/PDFs/initiation.pdf $>$.

Pi Alpha Xi. 2000c. National constitution of Pi Alpha Xi, Article II: chapters, section I, revised 1992-1994. 16 Apr. 2002. < http://www.pax.okstate.edu/PDFs/ c_bylaws.pdf $>$.
Pi Alpha Xi. 2000d. Pi Alpha Xi, chapter establishment. 16 Apr. 2002. <http:// www.pax.okstate.edu/chpestab.html>.

Pi Alpha Xi. 2000e. Pi Alpha Xi photography contest. 16 Apr. 2002. <http:// www.pax.okstate.edu/paxphoto.html>.

Pi Alpha Xi. 2000f. Pi Alpha Xi scholarship program. 16 Apr. 2002. <http:// www.pax.okstate.edu/paxschlr.html>.

Pi Alpha Xi. 2002a. Pi Alpha Xi, national intercollegiate floral crop quality evaluation and design competition. 16 Apr. 2002. <http://www.pax.okstate.edu/ paxfljg.html>.

Pi Alpha Xi. 2002b. Rules \& regulations for the $61^{\text {st }}$ annual national intercollegiate floral design competition. 16 Apr. 2002. <http://www.pax.okstate.edu/PDFs/ uwrf_dsnrules.pdf $>$.

Pi Alpha Xi. 2002c. Rules \& regulations for the $61^{\text {st }}$ annual national intercollegiate floral crop quality evaluation contest. 16 Apr. 2002. <http://www.pax. okstate.edu/PDFs/uwrf_judgrules.pdf>.

Pi Alpha XI. 2002d. Pi Alpha Xi, National honor society for floriculture, landscape horticulture, and ornamental horticulture. 16 Apr. 2002. <http://www.pax. okstate.edu>. 